\title{
CAP-reformi: maitopolitiikan muutokset ja vaikutukset Suomessa ${ }^{1}$
}

\author{
Jukka Kola1) ja Sami Kilpeläinen1) \\ 1) Taloustieteen laitos, Helsingin Yliopisto, PL 27, 00014 Helsingin yliopisto, \\ jukka.kola@helsinki.fi
}

\begin{abstract}
Johdanto
EU:n Agenda 2000:n maatalouspolitiikan välitarkastelun ja lopullisen, kesäkuun 2003 CAPreformin yhteydessä maitosektorille esitetään uudistuksia, joiden myötä EU:n maitomarkkinoiden hintataso ja rajasuoja on laskemassa ja tukijärjestelmä muuttumassa. Sen sijaan maidon kiintiöjärjestelmä säilyy ainakin aluksi, mutta reformin valmistelussa on esitetty myös kiintiöiden poistamista, johon paineet tulevaisuudessa edelleen kasvavat sekä sisäisesti että ulkoisesti.

Suomen maitomarkkinoiden kannalta maidon interventiohinnalla ja kiintiöillä on varsin suuri merkitys. Mikäli WTO-kierroksen tuloksena EU:n ajamat tavoitteet eivät mene läpi ja itälaajentuminen lisäisi runsaasti maitotuotteiden tarjontaa, EU:n sisämarkkinahinta voi laskea yli 20 prosenttia. Sen seurauksena Suomessa maidontuotanto laskisi huomattavasti. Siitä voisi puolestaan koitua oleellisia eroja alueelliseen kehitykseen, koska maidontuotannolla on edelleen suuri alueellinen ja maaseutupoliittinen merkitys koko maan kannalta.
\end{abstract}

\section{Tavoite ja metodologia}

Näiden politiikan eri keinojen vaikutusta Suomen maitomarkkinoille on tässä tutkimuksessa tarkasteltu vaihtoehtoisten politiikkaskenaarioiden $(4 \mathrm{kpl})$ kautta hyvinvointitaloustieteen ja kysyntä- ja tarjontateorioiden mukaisen yksinkertaistetun ja aggregoidun maitomarkkinamallin avulla.

\section{Politiikan vaihtoehdot ja keinot: CAP-reformi kesäkuu 2003}

Suomen maidontuotannon kannalta tukipolitiikalla on erityinen merkitys. Suomen liityttyä EU:n jäseneksi Suomi on maksanut kansallisista varoista maidolle tuotantotukia koko maassa. Vaikka maidon osalta kesäkuun 2003 CAP-reformi ei täyttä tuki-irrotusta esitäkään (full decoupling), EU:n yhteisen maatalouspolitiikan uudistuksen yhteydessä jatkossa tuotantoon sidottujen tukien tulevaisuus on kuitenkin vaakalaudalla, koska WTO:n rajoitteet estävät tuotantoon sidottujen tukien käyttöä.

Erityisesti Suomen ja koko EU:n kannalta tärkeää on se, kuinka hyvin EU pystyy ajamaan maatalouden monivaikutteisuutta (multifunctionality) erilaisten tukien perusteena, eli hyväksytäänkö pääosa EU:n maataloustuista WTO:n vihreään laatikkoon. Maidontuotannolla monivaikutteisuutta esiintyy usein enemmän kuin muilla tuotantosuunnilla, koska maidontuotanto työllistää enemmän kuin muut tuotantosuunnat ja myös tuottaa julkishyödykkeitä, kuten näkyviä maisema- ja kulttuuriarvoja, enemmän kuin muut tuotantosuunnat esimerkiksi kesäisen laiduntamisen ansiosta.

\footnotetext{
${ }^{1}$ Tämä tutkimus on osa Helsingin yliopiston Taloustieteen laitoksen ja Pellervon taloudellisen tutkimuslaitoksen yhteistutkimusprojektia MAITOSEKTORIN KANNATTAVUUS JA KILPAILUKYKY 2000-2010, josta on myös ilmestynyt julkaisu: Ylätalo, M. (toim.) 2002. Maitosektorin kannattavuus ja kilpailukyky 2000-2010. Helsingin yliopisto, Taloustieteen laitos, Julkaisuja nro 37. Maa- ja metsätalousministeriö on rahoittanut ko. projektia.
} 
Agenda 2000:n välitarkistus tarjosi maitosektorin osalta heinäkuussa 2002 aluksi neljä vaihtoehtoa:

(1) Agenda 2000:n jatkaminen

(2) Agenda 2000 -menettelyn toistaminen

(3) kaksihintakiintiöjärjestelmän käyttöönotto ja

(4) kiintiöiden poistaminen vuodesta 2008 alkaen.

\section{Tulokset ja johtopäätökset}

Maitomarkkinamalli osoittaa, että kiintiöiden poistosta Suomessa ei ole saatavissa vastaavia hyötyjä kuin eräissä EU-maissa (esim. Saksa), joissa kiintiöitä vuokrataan paljon, ja siksi kiintiöiden poiston seurauksena maidontuotannon rakennekehitys kiihtyy ja tuotantokustannukset alenevat, jolloin maidon tarjonta vahvistuu niissä maissa voimakkaasti. Mikäli maidon tarjonta on yksikköjoustavaa (e=1), Suomen maidontuotanto laskee arviolta 2000 miljoonan litran vuositasolle kiintiöiden poiston seurauksena vuonna 2010. Mikäli tarjonta on kuitenkin jäykempää $(\mathrm{e}=0,5)$, kokonaistarjonta vuonna 2010 olisi noin 2200 miljoonaa litraa, mikä tällä hetkellä näyttäisi todennäköisemmältä. Mikäli tarjonnan jousto oletetaan vielä jäykemmäksi $(\mathrm{e}=0,2)$, maidon tuotettu määrä olisi vuonna 2010 noin 2300 miljoonaa litraa kiintiöiden poiston seurauksena.

Tutkimusmetodologian ja tutkimustulosten sovellettavuuden kannalta on syytä ottaa huomioon, että tarjontajoustojen estimointi jo pitkään vahvasti hallinnollisesti säädellyltä maitosektorilta on vaikeaa. Siten eri joustovaihtoehtojen tuottamien tulosten, ns. herkkyysanalyysin, esittäminen on perusteltua.

Alunperin esitetyistä neljästä vaihtoehdosta kiintiöiden jatko olisi siis Suomen maidontuotannon kannalta paras vaihtoehto. Toisaalta Suomen kannalta edullinen tai ainakin mahdollinen voisi olla myös ns. AC-kiintiöjärjestelmä, edellyttäen että Suomen A-kiintiö vastaisi nykyistä maidontuotantoa. Jos kiintiöt kuitenkin jaettaisiin EU-maiden kotimaiseen kulutukseen suuntautuvan tuotannon perusteella, AC-kiintiöjärjestelmä olisi Suomen kannalta vaikea. Suomi vie suuren osan maidostaan tuetusti mm. Venäjälle, ja siksi vientitukien loppuminen AC-tukijärjestelmän myötä olisi Suomelle epäedullinen, koska ilman tukia vuotuisen noin 700 miljoonan litran vienti olisi vaikeaa.

Suomen maidontuotannon kannalta paras vaihtoehto tutkimuksessa esitetyistä skenaarioista olisi pehmeä WTO-ratkaisu ja vähävaikutteinen itälaajentuminen. Tällöin maidontuotanto voisi säilyä lähellä vuoden 2001 tasoa (2300-2400 miljoonaa litraa). Maitoreformin seurauksena hinnoissa on laskupaineita ainakin 15 prosenttia vuoden 2001 hinnoista. Tämän seurauksena kiintiöt eivät Suomessa olisi täyttymässä. Mikäli markkinahinnan kehitys on parempi tai tuet kannustavat tuottamaan enemmän, on Suomen maitokiintiöllä kuitenkin edelleen uhkana ylittyä, kuten viime vuosina on tapahtunut. Toisaalta jos maakiintiö olisi korkeampi, maidon vallitseva ylituotanto entisestään kasvaisi, jolloin maidon kotimarkkinahintaan Suomessa kohdistuisi ilmeisimmin voimakkaita laskupaineita.

Vientimahdollisuudet osaltaan vaikuttavat kotimarkkinahinnan kehitykseen, koska oleellinen osa (jopa 25-30 \%) maidostamme viedään ulkomaille, pääasiassa Venäjälle, erilaisina maitotuotteina. Koska maitotuotteiden vientinäkymät eivät näytä hyviltä tulevaisuudessakaan, on järkevää pyrkiä säilyttämään kotimarkkinoiden tasapaino mahdollisimman hyvin. Ulkomaan kaupan kannalta Venäjä on luonnollisesti mahdollisuus, ja samalla suuri epävarmuustekijä, Suomen maitotuotteiden viennin ja sitä kautta osaltaan myös kotimarkkinoiden hintakehityksen suhteen. Maailmanmarkkinoiden kehitykseen Suomi ei voi juurikaan vaikuttaa, mutta kotimarkkinoiden toimivuuteen voidaan vaikuttaa sekä politiikalla että maitomarkkinoiden toimijoiden omilla toimenpiteillä ja järkevällä yhteistyöllä. 


\section{Kirjallisuus}

Boone, K. \& van Bommel, K. 2001. Dairy policy without quota: Scenarios for the Netherlands and the European Union. Wageningen.

Boots, M. 1999. Micro-economic analysis of alternative policies for dutch dairy farming. 163 p. Wageningen.

Bouamra Mechemache, Z. \& Réguillart, V. 2000. Analysis of EU dairy policy reform. European Review of Agricultural Economics 27: 409-430.

Bundesministerium für Verbraucherschutz, Ernährung und Landwirtschaft. 2001. Vertrauen durch Veränderung. Arbeitsplan nachhaltige Landwirtschaft: Ein Positionspapier des Bundesministeriums für Verbraucherschutz, Ernährung und Landwirtschaft.

Burdych, J. 2001. Dairy sector in the Czech Republik: History and outlook. Saatavilla: http://www.mze.cz/cz/mleko/ download/prezentaceAJ.ppt. Viitattu 17.5.2002.

Burrell, A. 1989. Milk quotas in the European Community. 214 p. C.A.B. International, Wallingford.

Cahill, C. 2001. The multifunctionality of agriculture: What does it mean? EuroChoices Spring 2001: 36-41.

COPA/COGEGA. 2002. Reports on the Milk and Dairy Sector in different Candidate Countries. Meetings of Experts from the Candidate Countries with the COPA/COGEGA Working Party on Milk and Dairy Products.

European Court of Auditors (ECA). 2001. Special Report No 6/2001 (pursuant to Article 248, paragraph 4 (2), EC Treaty) on milk quotas. Saatavilla: www.eca.eu.int/EN/reports_opinions.htm. Viitattu 28.11.2001.

Elsig, M. 2001. The New WTO-Round and Eastern Enlargement of the EU: Overlapping negotiations and the Role of the EU-Commission in Agricultural Policy. Saatavilla: www.ciaonet.org/isa/elm01/. Viitattu: 14.11.2001.

Euroopan komissio. 1999. Yhteisen maatalouspolitiikan uudistus: maito ja maitotuotteet. $8 \mathrm{~s}$. Saatavilla: http://europa.eu.int/comm/dg06/index.htm. Viitattu: 6.8.2001.

Euroopan komissio. 2002. Laajentuminen ja maatalous - integraatiostrategia EU:n uusille jäsenvaltioille. IP/02/176.

European Commission. 2000a. Agriculture in the European union - Statistical and economic information 1999. Saatavilla: europa.eu.int/comm/agriculture/agrista/table_en. Viitattu: 5.2.2002.

European Commission. 2000b. Agenda 2000 CAP reform decisions - Impact analyses. 114 p.

European Commission. 2001a. Agriculture in the European Union - Statistical and economic information 2000. Saatavilla: europa.eu.int/comm/agriculture/agrista/table_en. Viitattu: 5.2.2002.

European Commission. 2001b. The Agricultural Situation in the European Union. 1999 report. Brussels, Luxembourg. 363 p.

European commission. 2001c. Prospects for agricultural markets 2001-2008. 152 p.

European commission. 2001d. Estimation of opportunity costs of own factors and total economic cost for milk production in the european union 1989/90-1999/2000. RI/CC 1341. $19 \mathrm{p}$.

European Commission. 2002a. Communication from the Commission to the Council and the European Parliament. Mid-term Review of the Common Agricultural Policy. Brussels. 35 p.

European Commission. 2002b. Commission working document - Report on milk quotas. Brussels. $38 \mathrm{p}$.

Ferrer, J. N. \& Emerson, M. 1999. Goodbye, Agenda 2000. Hello, Agenda 2003. CEPS Working Document No. 140.36 p.

Henrichsmeyer, W. 2000. Prospects for Agricultural Policy Reform: European Perspective. 11 p. IDF. 2000. IDF World Dairy Summit. Paperi esitetty: Dresden 16-20.9.2000, Saksa.

Jansson, T. 2002. Abolishing milk quotas- economic consequences for agriculture in Sweden and the EU. Paperi esitetty 24.4.2002 Brysselissä: "Conference on Future of Milk Regime".

Kaspersson, E., Rabinowicz, E. \& Schwaag Serger, S. 2002. EU milk policy after enlargement Competitiveness and politics in four candidate countries. Swedish Institute for Food and Agricultural Economics, report 2002:1. 107 p. 
Kilpeläinen, S. 2001. Elintarvikesektorin asema Itä-Suomen aluetaloudessa. Helsingin yliopiston taloustieteen laitoksen selvityksiä nro $15.68 \mathrm{~s}$. Helsinki.

Kleinhanss, W., Bertelsmeier, M., \& Offermann, F. 2001a. Phasing out of milk quotas - impacts on German agriculture. Paperi esitetty Workshopissa Pacioli 9, Braunschweig 11.14.11.2001.

Kleinhanss, W., Manegold, D., Bertelsmeier, M., Deeken, E., Giffhorn, E., Jägersberg, P., Offermann, F., Osterburg, B. \& Salamon, P. 2001b. Mögliche Auswerkungen eines Ausstiegs aus der Milchquotenregelung für die deutsche Landwirtschaft. 119 p. Saatavilla: www.bal.fal.de/default_X.html. Viitattu 17.1.2001.

Kola, J. 1991. Production control in Finnish agriculture. Determinants of Control Policy and Quantitative and Economic Efficiency of Dairy Restrictions. Agricultural Economics Research Institute, Research Publication 64. 133 p.

Kola, J., Marttila, J. \& Niemi, J. 1992. Maidontuotanto ja EY. Maatalouden taloudellisen tutkimuslaitoksen tiedonantoja $181.113 \mathrm{~s}$.

Meilke, K., Lariviére, S. \& Martin, C. 2001. Trade liberalization in the dairy sector: An overview. The Estey Centre Journal of International Law and Trade Policy 2: 118-145.

MMM. 2001. Maatalouden strategiaprojekti. Johtoryhmän loppuraportti. Työryhmämuistio MMM 2001:16. $65 \mathrm{~s}$.

Mäkimattila, M., Kallio, P. \& Marttila, J. 2001. Suomalaisen maidon liiketoimintaverkosto hinnoittelujärjestelmien kansainvälinen vertailu. PTT:n raportteja $179.59 \mathrm{~s}$.

Peltoniemi, A. \& Teivonen, M. 2002. EU:n laajentumisen vaikutukset maatalous- ja elintarvikemarkkinoilla. Maa- ja elintarviketalouden tutkimuskeskus, tutkimuksia $254.113 \mathrm{~s}$.

Pietilä, E. 1999. Maitokiintiön arvo ja hinta. Maatalouden taloudellisen tutkimuslaitoksen selvityksiä 10/1999. Helsinki. 37 s.

Sturgess, I. 1998. The future of the common agricultural policy. Paperi esitetty: RICS Research conference ROOTS '98. 19 p.

Svensk mjölk. 2000. Mjölk vision 2010. 112 s. Hållsta.

Swinbank, A. \& Tangermann, S. 2001. The future of direct payments under the CAP: A proposal. EuroChoices, Spring 2001: 28-35.

Swinnen, J. F. M. 2001. A Fischler reform of the Common Agricultural Policy? CEPS Working documents $173.50 \mathrm{p}$

Ukkonen, R. \& Kola, J. 1998. EU:n maitopolitiikka ja Agenda 2000. Helsingin yliopiston taloustieteen laitoksen selvityksiä nro 4. $121 \mathrm{~s}$. Helsinki.

Venstre. 2001. Folkenes og borgernes Europa. Saatavilla: http://venstre.dk/viewPage.php?id=736. WTO. 2001b. Canada - Measures affecting the importation of milk and the exportation of dairy products. Report of the Appelate Body AB-2001-6. 35 p.

Ylätalo, M. (toim.) 2002. Maitosektorin kannattavuus ja kilpailukyky 2000-2010. Helsingin yliopisto, Taloustieteen laitos, Julkaisuja nro 37.

Yrjölä, T. 2001. Kotieläintuotannon tuotantoetiikan taloudelliset vaikutukset - kirjallisuustutkimus. Teoksessa: Kola, J. (toim.). 2001. Elintarviketuotannon turvallisuuden ja etiikan ekonomiaa. Helsingin yliopiston taloustieteen laitoksen selvityksiä nro 14.

Yrjölä, T. \& Kola, J. 2001. Cost-benefit analysis of multifunctional agriculture in Finland. Agricultural and Food science in Finland 10: 295-307. 